\title{
FORMAÇÃO CONTINUADA DE PROFESSORES: CONTRIBUIÇÕES DA ABORDAGEM
} NARRATIVA (AUTO)BIOGRÁFICA

\author{
Caroline Carneiro Medeiros*, Inês de Souza Ferreira Bragança \\ Faculdade de Educação - UNICAMP \\ Conselho Nacional de Desenvolvimento Científico e Tecnológico
}

\section{Resumo a abordagem da narrativa (auto)biográfica. \\ Palavras-chave: \\ Formação de professores, Narrativas, Abordagem (auto)biográfica.}

O presente projeto focaliza a formação de professores/as, mais especificamente a formação continuada nas redes municipal e estadual de Campinas e sua aproximação com a Universidade Estadual de Campinas, tendo como suporte

\section{Introdução}

O presente pôster objetiva apresentar o trabalho de pesquisa-formação narrativa (auto)biográfica, tendo como foco a formação inicial de professores/as desenvolvida pela Faculdade de Educação da UNICAMP e a formação continuada, no contexto das escolas dos anos iniciais do Ensino Fundamental das redes estadual e municipal em Campinas.

\section{Metodologia}

A pesquisa-formação foi realizada a partir da abordagem narrativa (auto)biográfica, incluindo a escrita de um memorial de formação, a produção de um diário de itinerância (BARBIER, 2002), a participação no encontros de pesquisa-formação, tendo como eixo a escrita e a partilha de narrativas e o levantamento e estudo documental sobre a formação continuada no município de Campinas e na rede estadual de São Paulo.

\section{Desenvolvimento}

A pesquisa foi desenvolvida a partir de encontros de pesquisa-formação em/com escolas públicas da rede estadual e municipal de Campinas, em encontros do Grupo de Terça (organizado pelo Grupo de Estudos e Pesquisas em Educação Continuada - GEPEC) e com o Grupo de Pesquisa-Formação Polifonia (UERJ/UNICAMP), reuniões de orientação individual e coletivas.

O projeto da professora Inês Bragança, que se desdobra na proposta de IC realizada, tem como objetivo construir espaçostempos (BRAGANÇA, 2014) de formação continuada, por meio do diálogo entre escola e universidade, para isso foi formalizado um curso de extensão entre os professores/as e estudantes envolvidos nas disciplinas de estágio obrigatório da Unicamp. Esse espaçotempo é essencial para a construção de novas práticas pedagógicas instituintes a partir da reflexão acerca da escrita e partilha de narrativas, entrelaçadas às memórias, de modo a tornar o/a professor/a pesquisador de sua própria prática docente.

Esse entrelaçamento de memórias e narrativas torna o/a professor/a sujeito da história, pensando passado, presente e futuro através da linguagem, "passado, como memória; presente como ação e futuro como projeto ou espera" (BARBOSA, 2012, p. 151).
A formação docente é um processo complexo, ininterrupto e indissociável da formação pessoal do professor/a, portanto, ela está para além da formação inicial. As recentes políticas públicas de formação continuada legitimam espaçostempos formativos extraclasse, como a Lei 11.738 de julho de 2008, que incorpora a formação continuada como parte da jornada de trabalho do/a professor/a.

A presente pesquisa entende a narrativa pedagógica como elemento essencial na formação continuada, pois possibilita 0 processo de ação-reflexão-ação, onde experiências, memórias, reflexões e tomada de consciência se entrelaçam na construção de novas práticas itinerantes direcionadas à melhoria de uma prática social da educação. Esse movimento é chamado por Josso (2004) de pesquisa-formação, pois o pesquisador e sua prática são, simultaneamente, sujeitos da pesquisa.

Os processos de formação, tanto inicial quanto continuada, são essenciais para a profissão docente e, em ambas, a abordagem da narrativa (auto)biográfica é de extrema importância por possibilitar que o/a professor/a-pesquisador/a se entenda como sujeito histórico inacabado a partir da escrita individual e partilha de narrativas que entrelaçam vida pessoal, profissional e coletiva.

\section{Agradecimentos}

Agradeço ao Conselho Nacional de Desenvolvimento Científico e Tecnológico (CNPq) pelo apoio à pesquisa a partir da concessão de bolsa e financiamento do projeto.

BARBIER, René. A pesquisa-ação. Brasília: Plano Editora, 2002.

BARBOSA, Marialva. O presente e o passado como processo comunicacional. MATRIZes, São Paulo, Ano 5, 2012.

BRAGANÇA, Inês. Espaçostempos no Trabalho Docente: Narrativas de Professoras. In: Lúcia Velloso Maurício. (Org). Tempos e espaços escolares Experiências, políticas e debates no Brasil e no mundo. Rio de Janeiro: Ponteio/Faperj, 2014, v. 1, p. 89-102.

BRASIL. Lei 11.738 de 16 de julho de 2008. Regulamenta a alínea "e" do inciso III do caput do art. 60 do Ato das Disposições Constitucionais Transitórias, para instituir o piso salarial profissional nacional para os profissionais do magistério público da educação básica. Diário Oficial [da República Federativa do Brasil], Brasília, DF, 17 jul. 2008. P. 1. Disponível em: http://www.planalto.gov.br/ccivil_03/_ato2007-2010/2008/lei/111738.htm Acesso em: 08 jul. 2019.

JOSSO, Marie-Christine. As histórias de vida como territórios simbólicos nos quais se exploram e se descobrem formas e sentidos múltiplos de uma existencialidade evolutiva singular-plural. In: PASSEGGI, Maria Conceição (Org.). Tendências da pesquisa (auto) biográfica. Natal: EdUFRN: São Paulo: Paulus, 2008. p. 23-50. 